\title{
Percent Blasts in Peripheral Blood at Diagnosis
}

National Cancer Institute

\section{Source}

National Cancer Institute. Percent Blasts in Peripheral Blood at Diagnosis. NCI

Thesaurus. Code C158879.

A finding of the percentage of blasts in the peripheral blood at the time of diagnosis. 